\title{
Key to Opening Kidney for In Vitro-In Vivo Extrapolation Entrance in Health and Disease: Part I: In Vitro Systems and Physiological Data
}

\author{
Daniel Scotcher, ${ }^{1}$ Christopher Jones, ${ }^{2}$ Maria Posada, ${ }^{3}$ Amin Rostami-Hodjegan, ${ }^{1,4}$ and Aleksandra Galetin ${ }^{1,5}$
}

Received 9 March 2016; accepted 2 June 2016; published online 30 June 2016

\begin{abstract}
The programme for the 2015 AAPS Annual Meeting and Exhibition (Orlando, FL; 25-29 October 2015) included a sunrise session presenting an overview of the state-of-the-art tools for in vitro-in vivo extrapolation (IVIVE) and mechanistic prediction of renal drug disposition. These concepts are based on approaches developed for prediction of hepatic clearance, with consideration of scaling factors physiologically relevant to kidney and the unique and complex structural organisation of this organ. Physiologically relevant kidney models require a number of parameters for mechanistic description of processes, supported by quantitative information on renal physiology (system parameters) and in vitro/in silico drug-related data. This review expands upon the themes raised during the session and highlights the importance of high quality in vitro drug data generated in appropriate experimental setup and robust system-related information for successful IVIVE of renal drug disposition. The different in vitro systems available for studying renal drug metabolism and transport are summarised and recent developments involving state-of-the-art technologies highlighted. Current gaps and uncertainties associated with system parameters related to human kidney for the development of physiologically based pharmacokinetic (PBPK) model and quantitative prediction of renal drug disposition, excretion, and/or metabolism are identified.
\end{abstract}

KEYWORDS: active renal excretion; human kidney transporters; human renal drug clearance; kidney disease; non-hepatic drug metabolism.

\section{INTRODUCTION}

The recent paradigm shift to systems pharmacology approaches in drug development sets out an increased usage of quantitative concepts for linking in vitro observations on drug characteristics to their biological behaviour. Many

Electronic supplementary material The online version of this article (doi:10.1208/s12248-016-9942-x) contains supplementary material, which is available to authorized users.

$\overline{{ }^{1} \text { Centre for Applied Pharmacokinetic Research, Manchester Phar- }}$ macy School, University of Manchester, Stopford Building, Oxford Road, Manchester, M13 9PT, UK.

${ }^{2}$ DMPK, Oncology iMed, AstraZeneca R\&D Alderley Park, Macclesfield, Cheshire, UK.

${ }^{3}$ Drug Disposition, Lilly Research Laboratories, Indianapolis, Indiana 46203, USA.

${ }^{4}$ Simcyp Limited (a Certara Company), Blades Enterprise Centre, Sheffield, UK.

${ }^{5}$ To whom correspondence should be addressed. (e-mail: Aleksandra.Galetin@manchester.ac.uk)

ABBREVIATIONS ABC, ATP-binding cassette; ADME, Absorption, distribution, metabolism and excretion; BDDCS, Biopharmaceutical Drug Disposition and Classification System; CES, Carboxylesterase; $\mathrm{CHO}$, Chinese hamster ovary; $\mathrm{CL}_{\mathrm{CR}}$, Creatinine complex aspects of hepatic drug disposition have been addressed over the last decade using systems pharmacology approaches, with implications for population variability in pharmacokinetics (1), as well as adverse events in liver such as drug-induced liver injury (2). However, the same cannot be claimed for predicting renal disposition under various conditions or the covariates determining nephrotoxicity.

clearance; $\mathrm{CL}_{\mathrm{int}}$; Intrinsic clearance; $\mathrm{CL}_{\max }$, Maximal intrinsic clearance; CPPGK, Cytosolic protein per gram kidney; CYP, Cytochrome P450; DDI, Drug-drug interaction; GST, Glutathione$S$-transferase; HEK, Human embryonic kidney; IVIVE, In vitro-in vivo extrapolation; ISEF, Intersystem extrapolation factor; $K_{\mathrm{i}}$, Inhibition constant; LLC-PK1, Lewis lung carcinoma pig kidney; MALDI, Matrix-assisted laser desorption/ionisation; MATE, Multidrug and toxic compound extrusion; MDCK, Madin-Darby canine kidney; MPPGK, Microsomal protein per gram kidney; OAT, Organic anion transporter; OCT, Organic cation transporter; $P_{\text {app }}$, Apparent permeability; PBPK, Physiologically based pharmacokinetic; P-gp, P-glycoprotein; PTCPGK, Proximal tubule cells per gram kidney; QSPKR, Quantitative structure-pharmacokinetic relationship; REF, Relative expression factor; RAF, Relative activity factor; SLC, Solute carrier; UGT, Uridine diphosphate glucuronosyltransferase 
The kidneys have a significant role in the clearance of many drugs. Within the top 200 drugs prescribed in the USA in $2010,32 \%$ of them had $\geq 25 \%$ of the absorbed dose excreted unchanged in urine (3). The kidneys are also involved in drug metabolism due to expression of a number of drug-metabolising enzymes, as summarised in Table I. Mechanistic kidney models that mathematically describe underlying processes involved in renal drug disposition can be complex in order to capture the biological heterogeneity of this organ $(4,5)$.

Physiologically based pharmacokinetic (PBPK) models recognise different types of model parameters representing either properties of a drug, biological system and/or trial design, each requiring information from different sources $(1,6)$. System parameters are typically informed by quantitative data on the organ physiology, whereas data from in vitro experimental data can be used to inform drug-specific parameters. In vitro-in vivo extrapolation (IVIVE) is now a widely adopted approach for prediction of pharmacokinetic parameters from in vitro data ('bottomup'). IVIVE utilises scaling factors to account for differences between in vitro systems and in vivo situation (1). For example, microsomal metabolism data, reported as activity or intrinsic clearance $\left(\mathrm{CL}_{\mathrm{int}}\right)$ per milligram of microsomal protein, are scaled by the amount of microsomal protein per gram of the organ of interest, e.g. microsomal protein per gram kidney (MPPGK) in the case of kidney (7). Expression of a specific protein is accounted for by the relative expression factor (REF), which represents the ratio of the abundance of a particular protein (e.g. organic anion transporter (OAT) 3 (OAT3, $S L C 22 A 8)$ ) in the kidney in vivo compared with the expression in the cellular system used to generate the in vitro data $(5,8)$. Similarly, the relative activity factor (RAF) may be applied, which accounts for differences in activity of a protein of interest between in vivo and in vitro by using a selective probe substrate.

The overall aim of this two-part review is to analyse the current status and gaps in the knowledge required for quantitative prediction of renal drug disposition within the PBPK paradigm. The goal of part I is to outline the various sources of data required to inform parameters in IVIVEbased mechanistic kidney models to predict renal drug disposition. A critical overview of different in vitro tools currently available to investigate renal drug metabolism and transport is provided. The need for high quality in vitro drug data generated using appropriate experimental systems is emphasised. The second section of this paper critically assesses the current knowledge (and existing gaps) of the quantitative kidney anatomy and physiology data, of relevance for IVIVE renal scaling factors and PBPK system parameters. Part II of this review will focus on the availability, application and suitability of mechanistic models of renal drug excretion and/or metabolism, including the dynamics of drug disposition in kidney cells and the need for appropriate clinical data (Scotcher D, Jones C, Posada M, Galetin A, Rostami-Hodjegan, A., in preparation).

It should be noted that extensive review and listing of the multitude of enzymes and transporters which may be involved in the metabolism and excretion of drugs by the kidney are outside the scope of this review. For such information, readers are referred to previous studies and reviews (9-12).

\section{USE OF IN VITRO SYSTEMS TO UNDERSTAND RENAL DRUG ELIMINATION}

In vitro assays are routinely used during drug development to optimise the ADME properties of compounds and provide critical input to inform selection of appropriate dosing strategies in clinical trials. This information may relate to systemic or local tissue drug concentrations of relevance for the assessment of drug-drug interaction (DDI) risk and/or toxicity. Decision-making in drug development relies heavily on in vitro experimental data and subsequent modelling efforts. It is therefore essential that in vitro data are of high quality and generated using appropriate assay formats relevant for the scientific questions asked. It is also critical that any limitations of specific assays (e.g. inter and intralaboratory variability) and impact of data analysis (e.g. mechanistic modelling of in vitro data) on parameter values are understood by scientists involved in the translational implementation of such data using modelling and simulation.

\section{In Vitro Systems for Studying Renal Drug Metabolism}

Table I summarises the most relevant drug-metabolising enzymes expressed in the human kidney, together with the in vitro systems used and corresponding scaling factors necessary for IVIVE of renal metabolic clearance. Despite their physiological complexity, proximal tubule cells are not used on a regular basis for renal metabolism studies, mainly due to limited availability of high quality human kidney tissue. In addition, expression of key drug-metabolising enzymes in proximal tubule cells has been reported to reduce with time in culture (13). For certain drugs, potential impact of renal drug transporters expressed in proximal tubule cells also needs to be taken into consideration. Analogous to hepatocytes, IVIVE of renal metabolism in vitro data from isolated proximal tubule cells could be performed using proximal tubule cell number per gram kidney (PTCPGK) as a scaling factor.

It is evident from Table I that human kidney subcellular fractions (microsomes, S9) and recombinant enzyme expression systems are the most commonly applied sources of kidney drug-metabolising enzymes in in vitro assays (7, 1416). Subcellular fractions require supplementation with appropriate cofactors lost during the preparation procedure and these are highlighted in Table I. Kidney microsomes are the most frequently used system to investigate either cytochrome P450 (CYP) or glucuronidation (UGT)-mediated metabolism, whilst $9000 \mathrm{~g}$ supernatant (S9) or cytosolic preparations are considered if glutathione-S-transferase (GST) or carboxylesterase (CES)-mediated metabolism in the kidney are of relevance. Analogous to human liver microsomes, investigation of renal glucuronidation requires inclusion of alamethicin. This pore-forming peptide disrupts microsomal membranes to overcome reaction latency associated with UGTs due to localisation of the enzyme active site facing the lumen of the endoplasmic reticulum $(7,17)$. Furthermore, the addition of albumin has been implemented in the renal glucuronidation in vitro assays (7) in order to account for 
Table I. Summary of Key Drug-Metabolising Enzyme Isoforms in Human Kidney

\begin{tabular}{|c|c|c|c|c|c|}
\hline Protein & Other species & $\begin{array}{l}\text { Other organ } \\
\text { expression }\end{array}$ & $\begin{array}{l}\text { Kidney } \\
\text { distribution }\end{array}$ & Substrates & $\begin{array}{l}\text { Suitable in vitro } \text { system }+ \\
\text { cofactor/scaling factor }^{a}\end{array}$ \\
\hline CYP3A5 & Cynomolgus monkey & Liver and intestine & $\begin{array}{l}\text { Cortex and } \\
\text { medulla }\end{array}$ & $\begin{array}{l}\text { Ifosfamide, } \\
\text { cyclosporin A, } \\
\text { tacrolimus }\end{array}$ & $\begin{array}{l}\text { Human kidney microsomes + } \\
\text { NADPH/MPPGK } \\
\text { rhCYP/RAF }\end{array}$ \\
\hline CYP2D6 & Rat (CYP2D1-5) & Liver & $\begin{array}{l}\text { Paediatric; adult } \\
\text { expression } \\
\text { possibly low; } \\
\text { cortex > } \\
\text { medulla, highest } \\
\text { in PT and LoH }\end{array}$ & $\begin{array}{l}\text { Dextromethorphan, } \\
\text { bufuralol }\end{array}$ & $\begin{array}{l}\text { Human kidney microsomes }+ \\
\text { NADPH/MPPGK } \\
\text { rhCYP/RAF }\end{array}$ \\
\hline FMO1 & $\begin{array}{l}\text { Rat, mouse, } \\
\text { cynomolgus } \\
\text { monkey }\end{array}$ & $\begin{array}{l}\text { Liver of several } \\
\text { species but } \\
\text { not human }\end{array}$ & PT & $\begin{array}{l}S \text { - m e th y l N,N- } \\
\text { diethyldithiocarbom- } \\
\text { ate, sulphides }\end{array}$ & $\begin{array}{l}\text { Human kidney microsomes }+ \\
\text { NADPH/MPPGK } \\
\text { rhFMO/RAF }\end{array}$ \\
\hline $\mathrm{ADH} / \mathrm{ALDH}$ & Ubiquitous & Liver & $\begin{array}{l}\text { ADH: PT } \\
\text { A L D H : } \\
\text { throughout kidney }\end{array}$ & $\begin{array}{l}\text { ADH-alcohols, } \\
\text { ALDH-aldehyde } \\
\text { metabolites }\end{array}$ & $\begin{array}{l}\text { Human kidney cytosol + } \\
\text { NAD }^{+}(\mathrm{ADH}) \text { or } \mathrm{NADP}^{+} \\
\left(\mathrm{ALDH}^{-} / \mathrm{CPPGK}\right.\end{array}$ \\
\hline CES2 & Rat, mouse & Liver and intestine & $\begin{array}{l}\text { PT, Bowman's } \\
\text { capsule }\end{array}$ & Irinotecan, prodrugs & Human kidney S9/S9PPGK \\
\hline AKR1A1 & $\begin{array}{l}\text { Mouse/rat isoforms } \\
\text { differ to human }\end{array}$ & Ubiquitous & $\begin{array}{l}\text { PT, Bowman's } \\
\text { capsule }\end{array}$ & $\begin{array}{l}\text { Carbonyl containing } \\
\text { substrates, } \\
\text { daunorubicin }\end{array}$ & Human kidney S9/S9PPGK \\
\hline UGT1A9 & $\begin{array}{l}\text { UGT1A family in } \\
\text { most preclinical } \\
\text { species }\end{array}$ & Liver & PT, DT, LoH, CD & $\begin{array}{l}\text { Propofol, } \\
\text { mycophenolic acid, } \\
\text { lorcaserin, } \\
\text { edaverone }\end{array}$ & $\begin{array}{l}\text { Human kidney microsomes }+ \\
\text { UDPGA, alamethicin } \\
\text { MPPGK } \\
\text { rhUGT + UDPGA, saccharic } \\
\text { acid lactone } / \text { RAF }\end{array}$ \\
\hline UGT2B7 & $\begin{array}{l}\text { UGT2 family } \\
\text { members in most } \\
\text { preclinical species }\end{array}$ & Liver and intestine & PT, LoH, DT, CD & $\begin{array}{l}\text { Efavirenz, } \\
\text { zidovudine }\end{array}$ & $\begin{array}{l}\text { Human kidney microsomes + } \\
\text { UDPGA, alamethicin }{ }^{c} / \\
\text { MPPGK } \\
\text { rhUGT + UDPGA } / \text { RAF }\end{array}$ \\
\hline GSTM3 & $\begin{array}{l}\text { Cynomolgus, rhesus } \\
\text { monkey; GSTM } \\
\text { family members } \\
\text { in rat }\end{array}$ & Testis, brain & LoH, DT & Carmustine & $\begin{array}{l}\text { Human kidney cytosol + } \\
\text { GSH/CPPGK } \\
\text { Human kidney S9 + GSH/ } \\
\text { S9PPGK }\end{array}$ \\
\hline GSTP1 & $\begin{array}{l}\text { Rat, cynomolgus, } \\
\text { rhesus monkey }\end{array}$ & $\begin{array}{l}\text { Most organs, not } \\
\text { liver }\end{array}$ & $\begin{array}{l}\text { Podocytes, PT } \\
\text { (weak), } \\
\text { LoH, DT }\end{array}$ & $\begin{array}{l}\text { Ethacrynic acid, } \\
\text { chlorambucil }\end{array}$ & $\begin{array}{l}\text { Human kidney cytosol + } \\
\text { GSH/CPPGK } \\
\text { Human kidney S9 + GSH/ } \\
\text { S9PPGK }\end{array}$ \\
\hline MGST1/2/3 & $\begin{array}{l}\text { MGST family } \\
\text { members in most } \\
\text { preclinical species }\end{array}$ & Liver & $\begin{array}{l}\text { Cortex and } \\
\text { m e d u } 11 \text { a } \\
\text { collecting ducts, } \\
\text { endothelium }\end{array}$ & Chlorambucil (rat) & $\begin{array}{l}\text { Human kidney microsomes }+ \\
\text { GSH/MPPGK } \\
\text { Human kidney S9 + GSH/ } \\
\text { S9PPGK }\end{array}$ \\
\hline
\end{tabular}

References are provided in the supplementary material

$A D H$ alcohol dehydrogenase, $A K R$ aldo/keto reductase, $A L D H$ aldehyde dehydrogenase, $C D$ collecting duct, $C E S$ carboxylesterase, $C P P G K$ cytosolic protein per gram kidney, $C Y P$ cytochrome P450, DT distal tubule, $F M O$ flavin containing monooxygenase, GSH glutathione, GST glutathione- $S$-transferase, $L o H$ loop of Henle, $M G S T$ microsomal glutathione- $S$-transferase, $M P P G K$ microsomal protein per gram kidney, $N A D P H$ nicotinamide adenine dinucleotide phosphate, $P T$ proximal tubule, $P T C P G K$ proximal tubule cells per gram kidney, $R A F$ relative activity factor, $r h C Y P / r h U G T$ human enzyme in recombinant expression system, S9PPGK S9 protein per gram kidney, $S 9$ supernatant from $9000 \mathrm{~g}$ differential centrifugation, $U D P G A$ uridine diphosphate glucuronic acid, $U G T$ uridine diphospho-glucuronosyltransferase

${ }^{a}$ Freshly isolated human proximal tubule cells (expression of drug-metabolising enzymes rapidly decreases during cell culture) can be used for holistic drug metabolism assays, although enzymes expressed in other tubular regions (LoH, DT, CD) may not be represented-such data should be scaled using PTCPGK

${ }^{b}$ Differentiation from CYP-mediated metabolism challenging, although heat treatment $\left(45^{\circ} \mathrm{C}\right.$ for 2 min in absence of NADPH) is suggested to specifically inactivate FMO, whereas 1-aminobenzotriazole and methimazole are non-specific inhibitors of CYP and FMO enzymes, respectively

${ }^{c}$ Additional cofactors including $\mathrm{MgCl}_{2}$, saccharic acid lactone and bovine serum albumin have been proposed, although apparent benefits and optimal conditions vary between studies and UGT enzymes

the inhibitory effect of fatty acids released during microsomal incubations on UGTs. Although the 'albumin' effect is enzyme specific, its inclusion in the in vitro assay improved prediction accuracy of renal glucuronidation clearance when using microsomal data (7). Identification of the individual enzymes contributing to the overall renal metabolic clearance can be done through reaction phenotyping and use of selective chemical inhibitors. A number of selective inhibitors 
have been reported for UGT1A9 (e.g. niflumic acid and diflunisal) and UGT2B7 (e.g. fluconazole); however, some of these can also inhibit other UGTs, albeit at higher concentrations $(17,18)$. Consideration of the region of human kidney subcellular fractions used in drug metabolism studies is also of importance. Most studies use kidney cortex, but expression and activity of UGT and GST enzymes have also been demonstrated in the kidney medulla (Table I). In many cases, pooled kidney microsomes from either unspecified region or with no information on the proportion of the cortex and medulla are used in the renal metabolism studies. Analogous to hepatic CYPs and UGTs, evidence of atypical enzyme kinetics (i.e. not following standard MichaelisMenten behaviour) has been reported in human kidney microsomes (19). Such atypical kinetics requires appropriate modelling of in vitro data and subsequent IVIVE. For example, in the case of auto-activation, determination of maximal intrinsic clearance $\left(\mathrm{CL}_{\max }\right)$ is proposed as a substitute for standard $\mathrm{CL}_{\mathrm{int}}$ in the scaling process (20).

Recombinantly expressed metabolic enzymes are useful for determining the major enzymes responsible for the renal metabolism of a drug. High variability in abundance, not only between enzymes but also between batches for the same enzyme, has been reported for recombinantly expressed UGTs (e.g. 30.6\% coefficient of variation for rUGT1A4), which may hinder IVIVE-based prediction of both hepatic and renal glucuronidation clearance (14). In addition, UGTs expressed in insect cells may have a substantial amount of inactive protein present that can be reduced by lowering the amount of baculovirus used to infect cells (21). Therefore, the use of metabolic rate data from recombinant UGTs in a quantitative IVIVE setting may require correction for presence of inactive enzyme. Comparison of activity of probe substrates across various in vitro systems and/or batches to generate intersystem extrapolation factors (ISEF) should be considered for prediction of renal glucuronidation clearance from recombinant systems. These concepts are well established and widely used for IVIVE of CYP-mediated hepatic clearance from recombinant data (1). Emerging quantitative proteomic data on renal metabolic enzymes (15, 22), improved understanding of regional differences in their expression and differences in the enzyme expression in the microsomal/cellular systems relative to the kidney are crucial for the quantitative prediction of renal metabolic clearance; these challenges are discussed in more detail in part II.

\section{Measurement of Renal Passive Tubular Permeability In Vitro}

Quantitative prediction of renal excretion clearance requires consideration of each of the contributing processes, i.e. glomerular filtration, active secretion and tubular reabsorption. Passive renal tubular reabsorption of drugs has been correlated with drug lipophilicity and other physico-chemical properties $(23,24)$. Recently, a quantitative structurepharmacokinetic relationship (QSPKR) model has been developed for prediction of reabsorption clearance, although prior information on the dominant process (reabsorption or secretion) and/or Biopharmaceutical Drug Disposition and Classification System (BDDCS) class is required (25).

Currently, there is no consensus on the recommended in vitro system to assess renal passive tubular permeability in vitro. Some studies have proposed the use of permeability data following apical-basolateral transport across Lewis lung carcinoma pig kidney (LLC-PK1) cells for the assessment of tubular reabsorption in the human proximal tubule (26). Methods for culturing primary renal tubule cells have been published for the remaining sections of the nephron tubule (loop of Henle through collecting duct), but these are not routinely used for permeability and drug transport studies, e.g. (27). In contrast, the collecting duct-derived MadinDarby canine kidney (MDCK) cell line is routinely used for drug permeability and transport studies (following transfection with specific human drug transporters), typically in the context of oral drug absorption and brain penetration (28). Similarly, Caco- 2 cells are widely used as an in vitro model of intestinal, as well as blood-brain barrier permeability, and have recently been proposed as a possible in vitro model of passive renal tubular reabsorption (29). Caco-2 cells differ from kidney proximal tubule cells with respect to presence of mucosa, immune cells, apical receptors (megalin) and drug transporters (e.g. urate transporter 1 (URAT1/SLC22A12) and OAT4 (SLC22A11) are not present in Caco-2). Nevertheless, use of transporter inhibitors in the assay minimises the impact of transporter differences. This approach allows the data from a routine Caco-2 permeability assay to be scaled by corresponding tubular surface area to predict passive tubular reabsorption, as illustrated recently for 45 drugs (29). Such differences in physiological characteristics between cell lines (LLC-PK1, Caco-2 and MDCK) and renal tubule cells in different regions of the nephron need to be considered during data analysis and subsequent modelling exercises. In addition, performing permeability assay under the apical to basolateral $\mathrm{pH}$ gradient (e.g. of $\mathrm{pH} 6.5$ to 7.4 ) is important to mimic typical conditions observed in the renal proximal tubule. This is of particular relevance for basic drugs where use of the apparent permeability $\left(P_{\text {app }}\right)$ data obtained under isotonic $\mathrm{pH} 7.4$ conditions resulted in pronounced under-prediction of $\mathrm{CL}_{\mathrm{R}}$ (29).

\section{In Vitro Systems to Study Active Transport in Kidney}

Active tubular secretion and reabsorption in kidney are mediated by a number of drug transporters expressed in the epithelium of the proximal tubule cells. Summary of key drug transporters expressed in human and rodent kidney proximal tubule cells is shown in Table II. Various in vitro models to study active transport of drug in kidney have been reported, although a 'gold standard' assay format is currently lacking, as summarised in Table III. The selection of the most appropriate in vitro system will depend on the question/ hypothesis being investigated and constraints such as cost or availability of fresh human kidney tissue. There is some overlap with in vitro models used to investigate drug transport in the liver, as recently reviewed (31). Variability in transporter kinetic parameters observed between different experimental systems and laboratories and its implications will be addressed in more detail in part II.

\section{Transfected Cells}

Cell lines such as MDCK-II, Chinese hamster ovary (CHO), human embryonic kidney (HEK-293) and HeLa can 
Table II. Summary of Key Drug Transporters Expressed in Human and Rodent Kidney

\begin{tabular}{lllll}
\hline Transporter & Human? & \multicolumn{3}{c}{ Rat/mouse? } \\
\hline OCT2/Oct2 & $\checkmark$ & $\mathrm{BL}$ & $\checkmark$ & $\mathrm{BL}$ \\
OAT1/Oat1 & $\checkmark$ & $\mathrm{BL}$ & $\checkmark$ & $\mathrm{BL}$ \\
OAT2/Oat2 & $\swarrow$ & $\mathrm{BL}$ & $\curvearrowleft x$ & $\mathrm{AP}$
\end{tabular}

OAT4
Oat5
OCTN1/Octn1

OCTN2/Octn2

Octn3

PEPT1/Pept1

PEPT2/Pept2

MATE1/Mate1

MATE2-K

$\begin{array}{ll}\swarrow & \mathrm{BL} \\ \boldsymbol{\swarrow} & \mathrm{AP} \\ \qquad x & - \\ & ?\end{array}$

$\mathscr{\swarrow}$
AP

$-$

?

AP

AP

AP
AP

BL

$\stackrel{x}{x}$

$-$

AP

AP

AP

AP

AP

AP

AP

$-$

Comments

Relevance of OAT2 to transport in human kidney debated

Immunohistochemistry indicates Oat2 localised to loop of Henle in rat

Both positive and negative findings for expression in human kidney

\begin{tabular}{|c|c|c|c|c|}
\hline MDR1/Mdr1a and Mdr1b & $\swarrow$ & AP & $\checkmark x$ & $?$ \\
\hline MRP2/Mrp2 & $\swarrow$ & AP & $\boldsymbol{\swarrow}$ & AP \\
\hline MRP4/Mrp4 & $\swarrow$ & AP & $\swarrow$ & $?$ \\
\hline Oatp1a1 & $x$ & - & 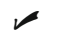 & AP \\
\hline Oatp1a3 & $x$ & - & $\prec$ & AP \\
\hline Oatp1a6 & $x$ & - & $\prec$ & $\mathrm{AP}$ \\
\hline OATP4C1/Oatp4c1 & $\swarrow$ & $?$ & $\nu$ & $?$ \\
\hline
\end{tabular}

Human MATE2-K belongs to class II subgroup of MATE transporters, no rodent ortholog exists; rodent Mate2, expressed predominantly in testes, belongs to class III subgroup and has been proposed to be renamed Mate3 but this is not in common use

Both positive and negative findings for expression in rodent kidney

Conflicting literature reports for rat Oatp4c1 localisation; apical localisation supported by functional activity data; human OATP4C1 localisation to basolateral membrane hypothesised based on functional activity data alone

Further details and references in the supplementary material, Tables S-I, S-II and S-III

$\checkmark$ strong evidence of expression in kidney, $\boldsymbol{x}$ transporter not present in particular species or not expressed in kidney, $\boldsymbol{\vee} \boldsymbol{x}$ evidence for expression in kidney is equivocal, $A P$ apical membrane, $B L$ basolateral membrane, - not relevant, ? not determined or conflicting data

be stably or transiently transfected to express renal drug transporters $(8,32,33)$. Transfected cell lines are widely used and commercially available and allow measurement of kinetic parameters for individual transporter(s) and drug combinations, including investigation of inhibitory potency as either $\mathrm{IC}_{50}$ or inhibition constants $\left(K_{\mathrm{i}}\right)$. Drug uptake and efflux can be studied simultaneously using multiple transfection of transporters in a single cell line $(32,34)$. Whilst tight control of transporter expression is possible (i.e. low between occasion variability), the relative expression, abundance and/or activity of multiple transporters in transfected cells may not necessarily represent the in vivo setting. Differences in transporter expression levels can be accounted for as REF scaling factors based on emerging proteomic abundance data (22); however, examples of this approach are limited for kidney and in some instances these scalars have been estimated using clinical data, as reported for pemetrexed
(8). Furthermore, expression $v s$. activity relationships need to be addressed both in vitro and in vivo before transporterspecific REFs can be used with confidence.

\section{Primary Cultured Renal Tubule Cells}

Primary renal tubule cells can be cultured in vitro for several cell generations whilst maintaining multiple characteristics of the cells of origin $(13,35)$. In addition, expression and function of several major drug transporters and enzymes are well maintained following a few days in culture, although reduced expression may be expected after longer culture times $(13,35,36)$. Such in vitro models of proximal tubule drug transport enable a holistic understanding of the processes; for example, reduction in functional activity due to inhibition or knockdown of one or more transporters can be investigated. Inter-individual variability can also be studied, 
Table III. Summary and Comparison of the Features on In Vitro Models for Active Secretion

\begin{tabular}{|c|c|c|c|c|c|c|}
\hline Feature & $\begin{array}{l}\text { Membrane } \\
\text { vesicles }\end{array}$ & Transfected cells & $\begin{array}{l}\text { Immortalised } \\
\text { kidney cell lines }\end{array}$ & $\begin{array}{l}\text { Primary cultured } \\
\text { renal tubule cells }\end{array}$ & Kidney slices & $\begin{array}{l}\text { Next generation } \\
\text { ('kidney-on-a-chip') }\end{array}$ \\
\hline $\begin{array}{l}\text { Transporter } \\
\text { expression }\end{array}$ & $\begin{array}{l}\text { Dependent on } \\
\text { source } \\
\text { (mammalian/ } \\
\text { insect cell } \\
\text { expression } \\
\text { system or } \\
\text { kidney tissue) }\end{array}$ & $\begin{array}{l}\text { Consistent } \\
\text { Can be controlled } \\
\text { in some systems } \\
\text { Differences to } \\
\text { kidney }\end{array}$ & $\begin{array}{l}\text { Consistent } \\
\text { Generally lower } \\
\text { than kidney }\end{array}$ & $\begin{array}{l}\text { Full complement } \\
\text { possible } \\
\text { Inter-individual } \\
\text { variability } \\
\text { Dependent on } \\
\text { culturing } \\
\text { conditions/tissue } \\
\text { quality }\end{array}$ & $\begin{array}{l}\text { Inter-individual } \\
\text { variability } \\
\text { Dependent on } \\
\text { tissue quality }\end{array}$ & Not yet investigated \\
\hline Availability & $\begin{array}{l}\text { Dependent on } \\
\text { source } \\
\text { (mammalian/ } \\
\text { insect cell } \\
\text { expression } \\
\text { system or } \\
\text { kidney tissue) }\end{array}$ & $\begin{array}{l}\text { Commercial } \\
\text { Cell culture } \\
\text { relatively } \\
\text { easy/routine }\end{array}$ & $\begin{array}{l}\text { Mixed availability, } \\
\text { some commercial }\end{array}$ & $\begin{array}{l}\text { Fresh human } \\
\text { kidney required } \\
\text { Expertise required } \\
\text { to isolate and } \\
\text { culture cells }\end{array}$ & $\begin{array}{l}\text { Fresh human } \\
\text { kidney required } \\
\text { Tissue slicer } \\
\text { required }\end{array}$ & $\begin{array}{l}\text { Very early stages of } \\
\text { development } \\
\text { Limited to a few } \\
\text { specialist laboratories }\end{array}$ \\
\hline $\begin{array}{l}\text { Physiological } \\
\text { representa } \\
\text { tion }\end{array}$ & Very limited & Very limited & $\begin{array}{l}\text { May lack some } \\
\text { transporters and } \\
\text { morphological } \\
\text { features }\end{array}$ & $\begin{array}{l}\text { Morphologically } \\
\text { representative } \\
\text { Lacks 3D } \\
\text { structure } \\
\text { Lacks other cells } \\
\quad \text { (endothelial } \\
\text { and interstitial) }\end{array}$ & $\begin{array}{l}\mathrm{M} \mathrm{o} \mathrm{s} \mathrm{t} \\
\text { physiology is } \\
\text { retained } \\
\text { Kidney region } \\
\text { (cortex/ } \\
\text { medulla) } \\
\text { should } \\
\text { be known }\end{array}$ & $\begin{array}{l}\text { Proposed to be better } \\
\text { than traditional in vitro } \\
\text { systems } \\
\text { Not yet demonstrated }\end{array}$ \\
\hline $\begin{array}{l}\text { Main } \\
\text { application }\end{array}$ & Efflux transport & $\begin{array}{l}\text { Screening assays } \\
\text { Transporter } \\
\text { kinetic parameters } \\
\left(K_{\mathrm{m}}, V_{\mathrm{max}}, K_{\mathrm{i}}\right)\end{array}$ & Toxicity & $\begin{array}{l}\text { Holistic uptake/ } \\
\text { transport studies } \\
\text { and assessment of } \\
\text { DDI potential }\end{array}$ & Uptake studies & Development ongoing \\
\hline Scaling factors & $\mathrm{REF} / \mathrm{RAF}$ & $\mathrm{REF} / \mathrm{RAF} / \mathrm{ISEF}$ & $\begin{array}{l}\text { Surface area } \\
\left(P_{\text {app }}\right) \\
\text { PTCPGK } \\
\quad \text { apparent } K_{\mathrm{m}} \\
\text { and } V_{\max } \\
\left.\text { or } \mathrm{CL}_{\text {int }}\right)^{a}\end{array}$ & $\begin{array}{l}\text { Surface } \\
\text { area }\left(P_{\text {app }}\right) \\
\text { PTCPGK } \\
\quad \text { apparent } K_{\mathrm{m}} \\
\text { and } V_{\max } \\
\left.\text { or } \mathrm{CL}_{\text {int }}\right)^{a}\end{array}$ & Kidney weight & $\begin{array}{l}\text { Allometric and } \\
\text { functional scaling } \\
\text { proposed (30) }\end{array}$ \\
\hline
\end{tabular}

${ }^{a}$ Additionally, REF/RAF scalars may be required to account for changes in expression/abundance/activity of transporters, which may occur during isolation, transfection (immortalised cells only) and/or cell culture

$D D I$ drug-drug interaction, ISEF intersystem extrapolation factor, $P T C P G K$ proximal tubule cells per gram kidney, $R E F$ relative expression factor (ratio of in vivo to in vitro expression), $R A F$ relative activity factor (ratio of in vivo to in vitro activity)

which should be distinguished from other factors such as differences in tissue quality and experimental variability. Extended research using primary cells depends on the availability of a consistent supply of quality human tissue, whilst obtaining reliable estimates of kinetic parameters, especially for specific transporters, can be challenging. As highlighted for renal metabolism, scaling of transporter kinetic parameters generated in tubular cells is performed using PTCPGK (Table III).

\section{Kidney Slices}

Kidney slices can be used to investigate drug uptake at the basolateral membrane but not tubular reabsorption (37, 38). An advantage of kidney slices is that the interactions of multiple substrates, inhibitors and endogenous transporters can be investigated in this complex system (38). Imaging technology (e.g. confocal microscopy, imaging mass spectrometry) can be used to support such studies and indicate the localisation of uptake and inhibition of renal drug transporter substrates, including those with therapeutic or toxicological effects in kidney $(39,40)$. The uptake of drugs in kidney slices can be affected by inter-batch and/or inter-individual variability (37), which must be considered for any IVIVE strategy, e.g. by normalising data against the relative activity/content of a marker in each kidney slice batch (38). The IVIVE of transporter kinetic data generated in this complex in vitro system is performed by kidney weight (Table III). The main limitation to wider application of human kidney slices is a consistent supply of quality tissue.

Other Cell Lines, Membrane Vesicles and 'Kidney-on-a-Chip'

Several cell lines derived from kidney such as LLC-PK1, Caki-1, HK-2, ci-PTEC, RPTEC/TERT1 and HKC have been characterised, with some commercially available (e.g. http:// www.lgcstandards-atcc.org/), and can be generally useful for investigating renal tubule function and toxicity in vitro (4144). For example ci-PTEC cells were used to investigate the impact of CYP3A5 and P-glycoprotein (P-gp/MDR1, ABCB1) genetic variation on tacrolimus metabolism, which could allow mechanistic insights into nephrotoxicity 
associated with this calcineurin inhibitor (44). The same system was used to demonstrate the inhibitory effect of uremic toxins (commonly accumulated in chronic kidney disease) on UGT activity which may have a significant impact on drug elimination in patients with renal impairment (45). An important limitation for some of these cell lines is that functional expression of drug transporters, particularly OAT1 (SLC22A6) and OAT3 (SLC22A8), or other renal characteristics can be lost (46), although some of the recent advanced molecular biology tools may be useful to overcome such issues (47).

Cell membrane vesicles can be isolated from tissue samples, cell lines and recombinantly expressed transporter systems $(48,49)$, allowing multiple or individual transporters to be studied. The inside-out vesicular transport assay is particularly useful for studying transport mediated by efflux transporters, which can be challenging when in standard cellbased assays. It should be noted that inside-out vesicles can be generated from overexpression systems but not usually from native kidney tissue. The use of membrane vesicles is limited to drugs with low lipophilicity/passive permeability. Drugs with high lipophilicity/permeability will show high levels of nonspecific binding to lipid bilayer of the vesicle and may not be trapped within the vesicles following uptake, making it difficult to measure transporter-related uptake rates (48).

Recent advances in molecular and cellular biology, combined with micro-engineering, have led to a number of proposed 'next-generation' in vitro models of the kidney and other organs. These models may incorporate features such as co-culture of multiple cell types (epithelium, endothelial and pericytes), fluid flow (e.g. microfluidic devices such as 'organon-a-chip') and 3D cell culture system, which have all been suggested to provide more physiologically representative in vitro systems for studying renal drug disposition $(30,50,51)$. Other emerging technologies, including stem cell science and 3D bio-printing, offer further potential for the development of the next-generation in vitro models (52). The application of these technologies to address questions on renal drug disposition and the translational value of the data generated remains a challenge for the future. A key question is whether next-generation in vitro models offer sufficient advantages over traditional methods to justify the additional effort and expertise required to generate suitable data.

\section{Mechanistic Modelling of in Vitro Transporter Kinetic Data}

Estimation of transporter kinetic parameters from in vitro assay data is a key step for successful IVIVE of transporter-mediated drug disposition, with recommendations recently published by the International Transporter Consortium (53). Important considerations pertinent also to IVIVE of renal clearance mediated via drug transporters are highlighted below.

Whilst uptake $\mathrm{CL}_{\text {int }}$ data can be used in IVIVE approaches, consideration of full kinetic profile in vitro (i.e. estimation of transporter $K_{\mathrm{m}}$ and $V_{\max }$ ) is preferable, to account for potential saturation issues (4, 53). Uptake transporter kinetic parameters can be estimated from cellbased in vitro uptake assays using the conventional two-step method (8). The main disadvantages of the two-step method are that data are generated using parallel experiments under different conditions (e.g. $37^{\circ} \mathrm{C}$ vs. $4^{\circ} \mathrm{C}$, transfected vs. mock transfected cells, standard media $v s$. media containing specific transporter inhibitor) and that bidirectional nature of passive permeability is not considered. An alternative method is the application of mechanistic compartmental modelling which relies on simultaneous fitting of uptake rates, bidirectional passive diffusion, intracellular binding and cellular metabolism (if relevant), as described for hepatocytes (54). The biggest constraint with such mechanistic models is the requirement for large amount of data (range of time points and substrate concentrations) to support parameter estimation. So far, complex mechanistic models have not yet been applied in the experimental settings and data analysis involving renal tubule cells.

Estimation of efflux transporter kinetic $\left(K_{\mathrm{m}, \mathrm{app}}, J_{\max }\right)$ and inhibition $\left(\mathrm{IC}_{50, \text { app }}\right)$ parameters is generally based on the use of extracellular medium concentrations of either substrate or inhibitors. Parameter estimates obtained this way are often dependent on expression levels of efflux transporters $(55,56)$, and this type of analysis is currently considered inadequate (53). Compartmental modelling approaches are recommended for estimation of mechanistic efflux transporter kinetic parameters in monolayer assays $(53,55,56)$. These models differ in their complexity and may also consider membrane partitioning and organelle (lysosomes) sequestration, ionised drug permeation, impact of the unstirred water layer and the contribution of electrochemical gradients (53, 56-59). The key advantage of these models is consideration of the interaction of an efflux transporter with the unbound intracellular drug concentration, as opposed to nominal incubation concentration. The application of such mechanistic models is vital for generation of mechanistic in vitro parameters describing kinetics of renal transporters to be used subsequently in PBPK models. This is of particular importance considering some of the complexities associated with renal transporters. For example, under appropriate in vitro conditions (e.g. expression system, $\mathrm{pH}$ gradient/ membrane potential), some renal drug transporters (including multidrug and toxin extrusion protein 1 (MATE1, SLC47A1) and 2-K (MATE2-K, SLC47A2) and OAT4 (SLC22A11) expressed on the apical membrane of proximal tubule cells in vivo can act as both uptake and efflux transporters $(8,32)$, highlighting the importance of careful interpretation of such in vitro data when translating to in vivo.

\section{UNDERSTANDING THE PHYSIOLOGY OF KIDNEY: THE KEY SYSTEM DATA IN PBPK MODELS}

Mechanistic kidney models represent a simplification of kidney anatomy and physiology (Fig. I) but due to the complexity of the organ may still incorporate a large number of parameters. In silico models of kidney physiology are typically implemented for rat $(61,62)$, for which detailed physiological system data are generally more widely available than for human, and are associated with a larger amount of in vivo and in situ measurements on relevant input-output relationships. This section will critically assess availability of human renal physiology data important to inform system parameters of mechanistic kidney PBPK models. In some instances, data from preclinical species may be used to bridge 


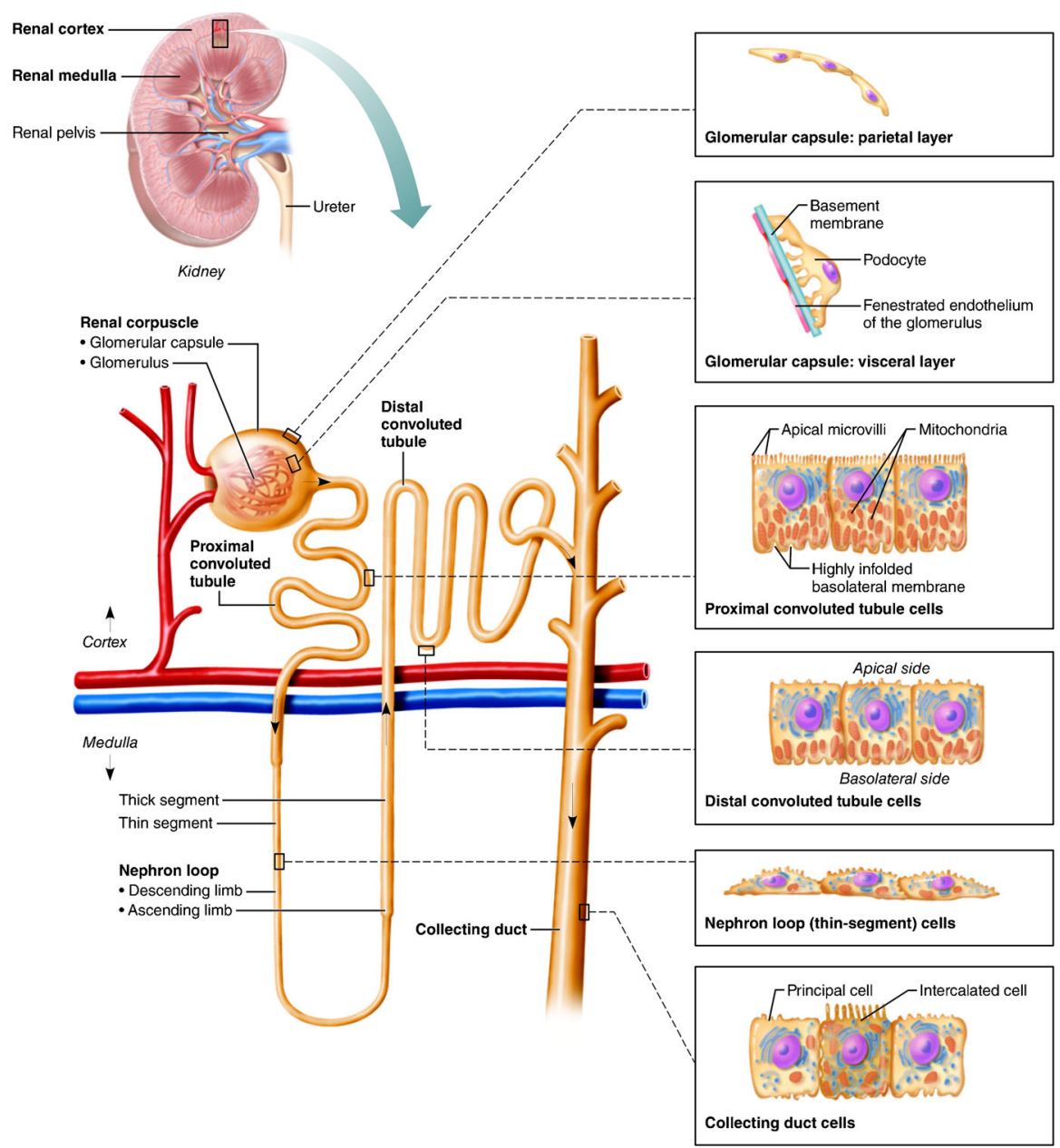

Fig. I. Schematic view of a nephron and collecting duct depicting the structural characteristics of epithelial cells forming various regions. Marieb, Elaine N.; Hoehn, Katja N., Human Anatomy \& Physiology, 10th, (02016, p. 966. Reprinted by permission of Pearson Education, Inc., New York, New York. (60)

the gap or uncertainty associated with the human physiological data and this will be indicated in sections below. Certain system parameters (e.g. protein expression) can be used in conjunction with the corresponding measurements for the in vitro system, to derive scaling factors (e.g. REF) for IVIVE of in vitro metabolism or transporter data, as highlighted below.

\section{Kidney Weight, Volume and Blood Flow}

Kidney weight or volume and renal blood flow are implemented as parameters in whole-body PBPK models, regardless of complexity of kidney model implemented, and are relevant to both renal excretion and renal metabolism of drugs. Kidney weight may also be used as an IVIVE scaling factor for in vitro data generated in kidney slice assays (Table III). Data on the weight and volume of human kidney, including potential covariation with factors such as age, gender, ethnicity, body weight and/or body height, have been reported and collated previously (7, 63-65). Inter-study variability may be low when using the same method to measure kidney size, whereas there appears to be systematic differences between the different methodological approaches
$(66,67)$. The decrease in kidney volume with age in adults (approx. $23 \mathrm{~mL}$ per decade after 50 years old) appears to be driven primarily by a decrease in cortical volume (approx. $18 \mathrm{~mL}$ per decade after 50 years old) (68). Data reported in paediatric populations have been collated and discussed elsewhere (69). Kidney weight and volume have been reported to both increase and decrease in kidney disease, depending on the stage and underlying cause of disease (Table IV). In fact, kidney size and cortical volume have been proposed as markers to aid diagnosis of kidney diseases (68, 70 ). Literature analysis of human kidney blood flow (average $16.4 \mathrm{~mL} / \mathrm{min} / \mathrm{kg}, 20 \%$ of cardiac output) and associated interindividual variability has been reported previously (7). The structural organisation of the intra-renal vasculature, intrinsic to the physiological functions of the kidney, has been well characterised $(71,72)$.

\section{Tubular Flow Rates and pH Regulation}

Glomerular filtration rate is a fundamental physiological parameter of mechanistic kidney models. This physiological parameter is often associated with inter-individual variability, 
Table IV. Example Literature Reports of Differences or Changes in Kidney Size in Relation to Renal Function in Different Forms/Aetiologies of Kidney Disease

\begin{tabular}{llll}
\hline Disease & Reported changes in & Comments & Methods \\
& kidney size with decrease & & \\
& in renal function ${ }^{a}$ & &
\end{tabular}

\begin{tabular}{ll}
\hline $\begin{array}{l}\text { Autosomal dominant } \\
\text { polycystic kidney }\end{array}$ & Increase (volume) \\
disease & \\
$\begin{array}{l}\text { Acquired cystic kidney } \\
\text { disease }\end{array}$ & Small decrease (length)
\end{tabular}

Hypertensive

Chronic ischaemic renal disease

Chronic glomerulonephritis

Diabetic nephropathy

Decrease (length)

Decrease (length) nephrosclerosis

Decrease (volume, length) Increase in early stages, decrease in later stages (length, volume)

$\begin{array}{ll}\text { HIV-associated } & \text { No changes found } \\ \text { nephropathy } & \text { Decrease (size) } \\ \text { CKD-aetiology } & \end{array}$

HIV-associated unspecified/mixed

\begin{abstract}
Rate of increase in kidney volume was equivalent to rate of increase in cyst volume

No differences or decrease in renal function and increase in kidney size associated with presence/absence of cysts in subjects without kidney failure
\end{abstract}

EBCT, MRI

Sonography
Spiral CTA, sonography

Sonography

Sonography

Prior to/during early kidney disease progression, moderately increased albuminuria is associated with glomerular hyperfiltration and increased renal volume in type 1 (insulin-dependent) diabetes and in some cases of type 2 (non insulindependent) diabetes

Sonography

Some results not significant Sonography

References are provided in supplementary material. No distinctions/inferences are made here regarding cause $v s$. effect relationships of renal size and renal function in the different diseases, as pathophysiological mechanisms of kidney disease can form a cycle of disease progression $C T A$ computed tomography angiography, CRF chronic renal failure, EBCT electron beam-computerised tomography, MRI magnetic resonance imaging

${ }^{a}$ Renal function assessed by various methods, including $\mathrm{CL}_{\mathrm{cr}}$, eGFR and $\mathrm{CL}_{\text {inulin }}$

as well as bias in the methods commonly used to estimate it. Wherever possible, mechanistic kidney models should be informed by measured glomerular filtration rate obtained using inulin or iothalamate as markers. However, as techniques for measuring glomerular filtration rate are challenging and resource intensive, creatinine urinary clearance $\left(\mathrm{CL}_{\mathrm{CR}}\right)$ is sometimes measured instead, despite evidence that tubular secretion contributes to $\mathrm{CL}_{\mathrm{CR}}$ (3). More frequently, $\mathrm{CL}_{\mathrm{CR}}$ and glomerular filtration rate are estimated from serum creatinine or cystatin $\mathrm{C}$ concentrations and demographic information (e.g. Cockcroft-Gault or modification of diet in renal disease equations) (73). Although accurate within the population group for which they are validated, these equations are typically imprecise and may not be accurate across populations. Alternative equations have been developed for infants and children (e.g. Schwartz equation, CounahanBarratt equation) (69). In addition, published data for glomerular filtration rate are usually normalised for body surface area (i.e. per $\mathrm{m}^{2}$ ). This normalisation may not be appropriate for obese subjects, as the absolute glomerular filtration rate $(\mathrm{mL} / \mathrm{min})$ has been found not to be proportional to body surface area in these patients (74). Furthermore, absolute glomerular filtration rate should be preferred for mechanistic kidney models, to be consistent with the standard use of clearance parameters.

Glomerular filtration rates in various population groups are widely reported in the literature. A brief summary is given here; for further information, interested readers should refer to the following reviews $(69,73-75)$. Average values for healthy young adult subjects are approximately $120-130 \mathrm{~mL} / \mathrm{min} / 1.73 \mathrm{~m}^{2}$. With respect to age, glomerular filtration rate (normalised to body surface area) increases rapidly after birth from around $20-30 \%$ of the adult value, reaching the adult level soon after 12 months of age (69). After the age of 30 years, glomerular filtration rate declines with ageing, although some uncertainties exist around the actual rate due to normal ageing, which has been reported at a loss of $7.5-16.6 \mathrm{~mL} / \mathrm{min} / 1.73 \mathrm{~m}^{2}$ per decade $(74,76)$. Glomerular filtration rate decreases in patients with renal impairment; in chronic kidney disease stages G1 (high and optimal), G2 (mild), G3a (mild-moderate), G3b (moderatesevere), G4 (severe) and G5 (kidney failure), glomerular filtration rates are $>90,60-90,45-59,30-44,15-29$ and $<15 \mathrm{~mL} / \mathrm{min} / 1.73 \mathrm{~m}^{2}$, respectively (73). Understanding of these physiological changes and their implementation in the mechanistic kidney models is key for the application of PBPK modelling to predict pharmacokinetics in special populations (e.g. obese or patients with renal impairment). 
Regional tubular flow rates are an important consideration in mechanistic models of passive tubular reabsorption. Overview of estimates of renal tubular flow rates in human kidney has been reported recently (29). Approximately 70$90 \%$ of filtrate is reabsorbed in the proximal convoluted tubule (29), whilst up to $15 \%$ of filtered water can appear in the urine during excessive water diuresis, when the distal tubule and collecting duct regions of the nephron become impermeable to water (77). Measurements of tubular filtrate reabsorption using the micro-puncture technique can be used to infer regional tubular flow rates; this technique is not possible in humans, although one study was found in rhesus monkey (78). Human tubular flow rates can also be inferred from differential changes in urine composition/flow rate in response to vasopressin levels between healthy and hereditary nephrogenic diabetes insipidus patients $(77,79)$. The micro-puncture technique can be used to study regional differences in tubular filtrate $\mathrm{pH}$; studies in rat indicate that the urine $(\mathrm{pH}$ 6.1) is more acidic than the proximal tubule filtrate $(\mathrm{pH}$ 6.7) in control conditions, but each of these can vary under different pathophysiological states such as acidosis (80).

\section{Nephron Number}

Nephron number can be an important system parameter in mechanistic kidney models as it allows scaling of data from a single nephron to the level of the whole kidney. For example, the tubular surface area of a single 'average' nephron can be used in conjunction with nephron number to estimate the total tubular surface area in the whole kidney. Nephron number has been extensively studied through the measurement of glomerular number $(64,65,81)$. Whilst there are about 900,000 nephrons per human kidney on average, large interindividual variability exists in human nephron number (ranging from 210,000 to 2.7 million (81)). Factors such as age, kidney weight and birth weight are being suggested as covariates, although such findings are generally inconsistent between studies $(65,81)$.

The collecting ducts form a branched tubular structure in the inner medulla, and each cortical collecting duct accepts the filtrate from several distal tubules (82). Therefore, there is a drastic reduction in the number of distinct tubules between the beginning of the cortical collecting ducts (approx. 90,000 per kidney) and the ducts of Bellini (approx. 250 per kidney); the implications of these on the estimation of the tubular surface area and subsequently prediction of tubular reabsorption have been published recently (29).

\section{Tubule Dimensions and Surface Area}

Tubular surface area and its regional differences are important consideration for mechanistic prediction of the extent of tubular reabsorption. In the mechanistic kidney models, tubular surface area is used as scaling factor for IVIVE of apparent permeability data from in vitro monolayer assays (Table III). Literature data on the dimensions of the proximal tubule, loop of Henle, distal tubule and collecting duct regions of the human nephron were recently collated (29). Data were found to be sparse, and reported values varied within and between studies. As an example, reported values of the length and diameter of the human proximal tubule ranged from 12 to $25.6 \mathrm{~mm}$ and 30 to $79.7 \mu \mathrm{m}$, respectively. Some of the variability may be attributed to age, as proximal tubule length increases during childhood and early adulthood, and declines after around 30-40 years old (63). In addition to the length, diameter and number of nephrons, the presence of plasma membrane structures such as microvilli, microplicae and basolateral infolding impact the estimate of the effective surface area for a given region of the nephron and subsequently prediction of the extent of tubular reabsorption.

\section{Proximal Tubule Cell Number}

The proximal tubule cell number is a system parameter in PBPK kidney models and is used as a scaling factor for IVIVE of transporter/metabolism in vitro data from cellbased assays (Table III), analogous to hepatocellularity. An estimate of the proximal tubule cell number in human kidney is currently not reported in the literature. Data exist in preclinical species, where a single study reported a mean number of rat proximal tubule cells of 92 million cells, with a corresponding mean kidney weight of $0.99 \mathrm{~g}$ (83). Stereology, which has been used for counting glomeruli number in kidney, is proposed as a suitable method for measuring absolute numbers of proximal tubule cells (83). In the absence of directly measured values, proximal tubule cell number can be inferred indirectly using relevant data from disparate literature sources (see Supplementary material for full details). Calculated values range from 30.2 to 209.2 million proximal tubule cells per gram kidney, in agreement with a report that 70 million cells, primarily of proximal tubule origin, can be isolated from $1 \mathrm{~g}$ of human renal cortical tissue (84). These calculated values are based on numerous assumptions and should therefore be treated as approximations.

\section{Microsomal and Cytosolic Protein Content of Kidney}

The amounts of microsomal and cytosolic protein in an organ are used as scaling factors for IVIVE of in vitro metabolism data generated in the corresponding subcellular fractions. In kidney, these scaling factors are the MPPGK and cytosolic protein per gram kidney (CPPGK). Summary of the four studies reporting microsomal recovery in kidney microsomes, i.e. MPPGK, is shown in Table V. There is over five-fold difference between the highest and lowest study averages, although data from the two most recent studies are in closer agreement $(15,85)$. It is interesting to note that the highest MPPGK value is reported for cortex (88), and this may be attributable to high amount of endoplasmic reticulum in cortex compared to medulla (15). Due to the low number of subjects (total of 23) and methodological differences (cortex vs. mixed kidney or unspecified region), it is challenging to assess the impact of potential covariates (e.g. age and gender) on the kidney microsomal protein content, as previously done for liver microsomal protein (89). No data currently 
Table V. Summary of Literature Reported Values for Human MPPGK and Corresponding MPPGL

\begin{tabular}{|c|c|c|c|c|c|c|}
\hline Study & $\begin{array}{l}\text { Mean } \\
\text { MPPGK } \\
\pm \text { SD }\end{array}$ & $\begin{array}{l}\text { Donor number } \\
(\text { Age } \pm \text { SD) } \\
{[\text { Number male] }}\end{array}$ & $\begin{array}{l}\text { Kidney tissue source } \\
\text { Kidney region } \\
\text { Fresh/frozen tissue }\end{array}$ & $\begin{array}{l}\text { Marker for } \\
\text { correction factor }\end{array}$ & $\begin{array}{l}\text { Microsomal } \\
\text { preparation } \\
\text { Centrifugation } \\
\text { stages }\end{array}$ & $\begin{array}{l}\mathrm{MPPGL} \pm \mathrm{SD} \\
(\text { Donor age } \pm \mathrm{SD}[n])\end{array}$ \\
\hline $\begin{array}{l}\text { Knights } \\
\quad \text { et al. (15) }\end{array}$ & $9.3 \pm 2.0$ & $\begin{array}{l}5 \\
(68.6 \pm 10.7) \\
{[3]}\end{array}$ & $\begin{array}{l}\text { Tumour } \\
\text { Mixed (cortex } \\
\text { and medulla) } \\
\text { Not specified }\end{array}$ & $\begin{array}{l}\text { NADPH cytochrome } \\
\text { c reductase }\end{array}$ & $\begin{array}{l}10,000 \times g \\
100,000 \times g\end{array}$ & NA \\
\hline $\begin{array}{l}\text { Al-Jahdari et } \\
\text { al. }(85)\end{array}$ & $12.8 \pm 7.1$ & $5(67.2 \pm 12.3)[4]$ & $\begin{array}{l}\text { Renal tumour } \\
\text { Region not specified } \\
\text { Frozen }\end{array}$ & $\begin{array}{l}\text { NADPH } \\
\text { cytochrome } \\
\text { c reductase }\end{array}$ & $9000 \times g(86)$ & NA \\
\hline $\begin{array}{l}\text { Pacifici et al. } \\
\text { (87) }\end{array}$ & $5.3 \pm 0.3$ & $8(53 \pm 16.0)[2]$ & $\begin{array}{l}\text { Not specified } \\
\text { Region not specified } \\
\text { Frozen }\end{array}$ & $\begin{array}{l}\text { None specified, } \\
\text { protein content } \\
\text { measured }\end{array}$ & $\begin{array}{l}9000 \times g \\
105,000 \times g\end{array}$ & $32.3 \pm 2.3(36 \pm 7[6])^{a}$ \\
\hline $\begin{array}{l}\text { Jak obss on } \\
\text { and Cinti } \\
(88)\end{array}$ & $32.0 \pm 5.4$ & $5(52.8 \pm 18.2)[5]$ & $\begin{array}{l}\text { Post-mortem } \\
\text { Cortex } \\
\text { Fresh }\end{array}$ & $\begin{array}{l}\text { Glucose-6- } \\
\text { phosphatase }\end{array}$ & $\begin{array}{l}12,000 \times g \\
105,000 \times g\end{array}$ & NA \\
\hline $\begin{array}{l}\text { Weighted } \\
\text { mean } \pm \text { SD }\end{array}$ & $13.6 \pm 11.0$ & $(59.4 \pm 16.6)$ & & & & \\
\hline
\end{tabular}

$M P P G K$ microsomal protein per gram of kidney, $S D$ standard deviation

${ }^{a}$ Predicted MPGGL for a 36-year-old is $39.4 \mathrm{mg}$ protein/g liver, using model proposed by Barter et al. [89]

exist for human CPPGK, and research is ongoing to expand the available data for human MPPGK (90).

\section{Amount of Specific Drug Metabolising Enzymes in Kidney}

Drug-metabolising enzyme expression data can be used as system parameters in PBPK models in order to account for inter-individual variability in drug metabolism. Expression and activity data suggest that UGT1A9 and UGT2B7 are the major UGT enzymes in human kidney, with UGT1A9 expressed at levels close to or higher than those measured in liver (91). These findings are in agreement with the majority of quantitative abundance data from commercially available pooled human kidney microsomes, acquired using targeted LC-MS/MS proteomic methods (14, 92). Large variability in both mRNA $(72-85 \% \mathrm{CV}, n=11)$ and protein abundance $(76-159 \% \mathrm{CV}, n=10)$ has been noted for UGT1A6, 1A9 and 2B7 in kidney homogenates prepared from unspecified regions of healthy kidney (93). Lower expression and abundances were observed in tumoral kidney homogenates, although variability reported was comparable to those in healthy kidney (93). In contrast to homogenates, lower variability in UGT1A6, 1A9 and 2B7 abundance was reported in microsomes from human kidney cortex (48-61\% $\mathrm{CV}, n=5)$, mixed kidney (32-44\% CV, $n=5)$ and kidney medulla (15). The differences in the two studies could be due to the low number of individual samples, which may not be sufficient to accurately determine inter-individual variability, or contribution of technical variabilities which were not assessed in either study. Absolute abundance data generated using targeted LC-MS/MS can vary between studies and laboratories (94); therefore, further work is required to assess inter-laboratory variability to facilitate standardisation of proteomic methods.

\section{Amount of Specific Drug Transporters in Kidney}

PBPK kidney models include system parameters to account for transporter expression and associated interindividual variability in these data. IVIVE of transporter kinetic data from cellular in vitro systems is performed by REF scalars to account for differences in the expression between in vivo and in vitro (Table III). Several studies have measured the mRNA levels of the kidney drug transporters, e.g. $(3,37,46)$; the overall trends suggest substantial inter-individual variabilities in the expression of drug transporters, consistent with limited available functional activity data (37). Quantitative proteomic transporter abundance data are available for human organs such as intestine, liver and brain (95-97), as well as rat kidney (98). Data for human kidney have recently been published; of the solute carrier transporters (SLC), MATE1 and OAT3 were the most abundant (10.8 and $9.7 \mathrm{pmol} / \mathrm{mg}$ microsomal protein, respectively), whereas $\mathrm{P}$ gp/MDR1 was the most abundant ATP-binding cassette (ABC) transporter (4.45 pmol/mg microsomal protein) (22). Although data are available concerning renal developmental patterns of transporters in rodent species, minimal expression data are available for human (99). LC-MS/MS methods are currently favoured for measuring transporter abundance in tissue homogenates and subcellular fractions due to the high precision and ability to assess inter-individual and inter-study variability in transporter expression (96). Complimentary technologies such as matrix-assisted laser desorption/ionisation (MALDI)imaging mass spectrometry, secondary ion mass spectrometry and flow cytometry $(100,101)$ may allow quantitative analysis of transporter localisation at the 
tissue and/or subcellular scales (e.g. total protein vs. functional protein) to be possible in the future. However, secondary ion mass spectrometry-based methods require further development before analysis of large proteins such as drug transporters is possible (100).

\section{PERSPECTIVE ON CURRENT EFFORTS}

This review provides a critical analysis of different in vitro tools currently available to investigate renal drug metabolism and transport, in conjunction with key system parameters necessary for mechanistic 'bottom-up' prediction of renal drug disposition. Selection of suitable in vitro assays and experimental design should be driven by the scientific question(s) and properties of the compound of interest. For example, transfected cell lines or recombinant enzyme expression systems may be more suitable for investigating the interaction of drugs with individual transporters or enzymes, whereas primary cultured proximal tubule cells are more appropriate when a holistic understanding of the interplay of different processes is required (Table III). Potential limitations of each system, as well as details of assay design (e.g. appropriate time points, bio-analysis methodology), must be considered to ensure that quality and fit-for-purpose in vitro data are acquired. The importance of optimisation of assay conditions should not be underestimated. It is expected that the wide range of in vitro systems currently available to study renal drug disposition will be expanded by ongoing research. Efforts to develop novel in vitro platforms to investigate nephrotoxicity rely on molecular biology and micro-engineering technologies to improve physiological features of cells cultured in vitro to mimic renal cells in vivo $(47,50,51)$. Systems developed for the purpose of toxicity screening that feature active expression of relevant drug-metabolising enzymes and transporters may also be useful for studying renal drug disposition in vitro, in order to generate data for prediction of pharmacokinetic parameters.

System data represent an essential component of PBPK models allowing quantitative extrapolation to other populations/patients/scenarios. Ongoing work aimed at measurement of protein abundances of renal drugmetabolising enzymes and drug transporters remains a high priority. Additional studies to assess the consistency of proteomic methods and cross-laboratory comparisons of abundance data using the same biological samples are needed to differentiate between biological and technical variability in expression levels. Once available, abundance data from large cohorts of individuals could allow for covariates and protein-protein correlations to be established whilst assessing the impact of particular demographic features such as age and renal impairment. Sample availability in particular patient groups will remain a substantial limitation in the generation of these data. In particular, paediatric PBPK models require information on the ontogeny of the abundance and activity of drugmetabolising enzymes and transporters; in contrast to hepatic drug-metabolising enzymes, such data are lacking for human kidney $(99,102)$. Using suitable techniques to quantify differences in protein abundance in different regions of the nephron, such as the convoluted vs. straight portion of proximal tubule, would allow refinement of the current mechanistic models (5). Some system data can be measured in both human and preclinical species (e.g. blood flow, microsomal protein recoveries, proximal tubule cellularity and protein abundances) and for those parameters species differences can be established. For other physiological features such as regional tubular filtrate flow rates and $\mathrm{pH}$, where direct access to the intact, functional kidney is required for measurements, data from preclinical species may be used as surrogate for systems parameters in models of human kidney.

The uncertainties around parameters such as filtrate flow rate and $\mathrm{pH}$ may eventually limit the level of complexity that can be built into mechanistic models of human kidney (or the level of certainty in absolute values of systems parameters in complex models). This contrasts with published models of rat kidney, for which the available data support the mathematical description of features such as exponential decline in proximal tubule filtrate flow and compliant tubules (61). Despite uncertainties associated with some human kidney systems parameters, recent modelling efforts have attempted to account for the impact of flow rates and $\mathrm{pH}$ on tubular drug reabsorption (29), as well as the effects electrochemical gradients on organic cation transporter (OCT) 2 (OCT2, SLC22A2)-mediated secretion (59) in mechanistic kidney models. The importance of accounting for the impact of urine $\mathrm{pH}$ on proton gradient-dependent drug transport by MATE1 and MATE2-K, as described in vitro (103), should also be assessed.

\section{CONCLUSION}

Physiologically based prediction of renal clearance depends on both high quality in vitro data and sufficient knowledge of human physiology in different population groups. As highlighted, various kidney in vitro systems are currently available but generally lack the level of characterisation seen for hepatic in vitro systems and corresponding models. More complex in vitro systems such as those involving micro-fluidics require sophisticated in vitro modelling in order to obtain parameters of translational relevance. Quantitative renal physiology data important to inform mechanistic kidney model parameters have been summarised here. It is evident that given the complexity of these models and large number of system parameters, a number of knowledge gaps still exist, especially in our understanding of changes in physiological parameters in special populations. These can arise because of ethical constraints, difficulties in obtaining human kidney tissue (particularly for paediatrics or renal impairment) or technological limitations. Development of novel technologies, such as progresses in quantitative proteomics, should allow generation of data that are currently lacking to refine further PBPK-IVIVE of renal drug disposition. 


\section{ACKNOWLEDGMENTS}

D.S. was supported by a $\mathrm{PhD}$ studentship from the Biotechnology and Biological Sciences Research Council UK (BB/J500379/1) and AstraZeneca, Cambridge, UK. Part of this work was presented at AAPS Annual Meeting 2015, Orlando, FL. The authors would like to acknowledge the assistance of Eleanor Savill in preparing this manuscript.

Open Access This article is distributed under the terms of the Creative Commons Attribution 4.0 International License (http://creativecommons.org/licenses/by/4.0/), which permits unrestricted use, distribution, and reproduction in any medium, provided you give appropriate credit to the original author(s) and the source, provide a link to the Creative Commons license, and indicate if changes were made.

\section{REFERENCES}

1. Rostami-Hodjegan A. Physiologically based pharmacokinetics joined with in vitro-in vivo extrapolation of ADME: a marriage under the arch of systems pharmacology. Clin Pharmacol Ther. 2012;92(1):50-61.

2. Shoda LK, Woodhead JL, Siler SQ, Watkins PB, Howell BA. Linking physiology to toxicity using DILIsym ${ }^{\circledR}$, a mechanistic mathematical model of drug-induced liver injury. Biopharm Drug Dispos. 2014;35(1):33-49.

3. Morrissey KM, Stocker SL, Wittwer MB, Xu L, Giacomini KM. Renal transporters in drug development. Annu Rev Pharmacol Toxicol. 2013;53(1):503-29.

4. Felmlee MA, Dave RA, Morris ME. Mechanistic models describing active renal reabsorption and secretion: a simulation-based study. AAPS J. 2013;15(1):278-87.

5. Neuhoff S, Gaohua L, Burt H, Jamei M, Li L, Tucker GT, et al. Accounting for transporters in renal clearance: towards a mechanistic kidney model (Mech KiM). In: Sugiyama Y, Bente $\mathrm{S}$, editors. Transporters in drug development. New York: Springer; 2013. p. 155-77.

6. Galetin A. Rationalizing underprediction of drug clearance from enzyme and transporter kinetic data: from in vitro tools to mechanistic modeling. In: Nagar S, Argikar UA, Tweedie DJ, editors. Enzyme kinetics in drug metabolism: fundamentals and applications. Clifton, NJ: Springer; 2014. p. 255-88.

7. Gill KL, Houston JB, Galetin A. Characterization of in vitro glucuronidation clearance of a range of drugs in human kidney microsomes: comparison with liver and intestinal glucuronidation and impact of albumin. Drug Metab Dispos. 2012;40(4):825-35.

8. Posada MM, Bacon JA, Schneck KB, Tirona RG, Kim RB, Higgins JW, et al. Prediction of renal transporter mediated drug-drug interactions for pemetrexed using physiologically based pharmacokinetic modeling. Drug Metab Dispos. 2015;43(3):325-34.

9. Nishimura M, Naito S. Tissue-specific mRNA expression profiles of human phase I metabolizing enzymes except for cytochrome P450 and phase II metabolizing enzymes. Drug Metab Pharmacokinet. 2006;21(5):357-74.

10. Lohr JW, Willsky GR, Acara MA. Renal drug metabolism. Pharmacol Rev. 1998;50(1):107-41.

11. Hillgren KM, Keppler D, Zur A, Giacomini KM, Stieger B, Cass CE, et al. Emerging transporters of clinical importance: an update from the International Transporter Consortium. Clin Pharmacol Ther. 2013;94(1):52-63.

12. Giacomini KM, Huang S-M, Tweedie DJ, Benet LZ, Brouwer $\mathrm{KL}$, Chu X, et al. Membrane transporters in drug development. Nat Rev Drug Discov. 2010;9(3):215-36.
13. Lash LH, Putt DA, Cai H. Drug metabolism enzyme expression and activity in primary cultures of human proximal tubular cells. Toxicology. 2008;244(1):56-65.

14. Fallon JK, Neubert H, Goosen TC, Smith PC. Targeted precise quantification of 12 human recombinant uridine-diphosphate glucuronosyl transferase $1 \mathrm{~A}$ and $2 \mathrm{~B}$ isoforms using nano-ultrahigh-performance liquid chromatography/tandem mass spectrometry with selected reaction monitoring. Drug Metab Dispos. 2013;41(12):2076-80.

15. Knights KM, Spencer SM, Fallon JK, Chau N, Smith PC, Miners JO. Scaling factors for the in vitro-in vivo extrapolation (IV-IVE) of renal drug and xenobiotic glucuronidation clearance. Br J Clin Pharmacol. 2016. doi:10.1111/bcp.12889.

16. Nishimuta H, Houston JB, Galetin A. Hepatic, intestinal, renal, and plasma hydrolysis of prodrugs in human, cynomolgus monkey, dog, and rat: implications for in vitro-in vivo extrapolation of clearance of prodrugs. Drug Metab Dispos. 2014;42(9):1522-31.

17. Walsky RL, Bauman JN, Bourcier K, Giddens G, Lapham K, Negahban A, et al. Optimized assays for human UDPglucuronosyltransferase (UGT) activities: altered alamethicin concentration and utility to screen for UGT inhibitors. Drug Metab Dispos. 2012;40(5):1051-65.

18. Miners JO, Mackenzie PI, Knights KM. The prediction of drugglucuronidation parameters in humans: UDPglucuronosyltransferase enzyme-selective substrate and inhibitor probes for reaction phenotyping and in vitro-in vivo extrapolation of drug clearance and drug-drug interaction potential. Drug Metab Rev. 2010;42(1):196-208.

19. Gaganis P, Miners JO, Brennan JS, Thomas A, Knights KM. Human renal cortical and medullary UDPglucuronosyltransferases (UGTs): immunohistochemical localization of UGT2B7 and UGT1A enzymes and kinetic characterization of S-naproxen glucuronidation. J Pharmacol Exp Ther. 2007;323(2):422-30.

20. Houston JB, Galetin A. Modelling atypical CYP3A4 kinetics: principles and pragmatism. Arch Biochem Biophys. 2005;433(2):351-60.

21. Zhang H, Patana A-S, Mackenzie PI, Ikushiro S, Goldman A, Finel M. Human UDP-glucuronosyltransferase expression in insect cells: ratio of active to inactive recombinant proteins and the effects of a C-terminal his-tag on glucuronidation kinetics. Drug Metab Dispos. 2012;40(10):1935-44.

22. Nakamura K, Hirayama-Kurogi M, Ito S, Kuno T, Yoneyama T, Obuchi W, et al. Large-scale multiplex absolute protein quantification of drug-metabolizing enzymes and transporters in human intestine, liver and kidney microsomes by SWATHMS: comparison with MRM/SRM and HR-MRM/PRM. Proteomics. 2016; doi: 10.1002/pmic.201500433.

23. Paine SW, Barton P, Bird J, Denton R, Menochet K, Smith A, et al. A rapid computational filter for predicting the rate of human renal clearance. J Mol Graphics Model. 2010;29(4):529-37.

24. Varma MV, Feng B, Obach RS, Troutman MD, Chupka J, Miller HR, et al. Physicochemical determinants of human renal clearance. J Med Chem. 2009;52(15):4844-52.

25. Dave RA, Morris ME. Quantitative structure-pharmacokinetic relationships for the prediction of renal clearance in humans. Drug Metab Dispos. 2015;43(1):73-81.

26. Kunze A, Huwyler J, Poller B, Gutmann H, Camenisch G. In vitro-in vivo extrapolation method to predict human renal clearance of drugs. J Pharm Sci. 2014;103(3):994-1001.

27. Mooren FC, Kinne RK. Intracellular calcium in primary cultures of rat renal inner medullary collecting duct cells during variations of extracellular osmolality. Pflugers Arch. 1994;427(5-6):463-72.

28. Irvine JD, Takahashi L, Lockhart K, Cheong J, Tolan JW, Selick H, et al. MDCK (Madin-Darby canine kidney) cells: a tool for membrane permeability screening. J Pharm Sci. 1999;88(1):28-33.

29. Scotcher D, Jones C, Rostami-Hodjegan A, Galetin A. Novel minimal physiologically-based model for the prediction of passive tubular reabsorption and renal excretion clearance. Eur J Pharm Sci. 2016. doi:10.1016/j.ejps.2016.03.018. 
30. Wikswo JP, Curtis EL, Eagleton ZE, Evans BC, Kole A, Hofmeister LH, et al. Scaling and systems biology for integrating multiple organs-on-a-chip. Lab Chip. 2013;13(18):3496-511.

31. Brouwer KL, Keppler D, Hoffmaster KA, Bow DA, Cheng Y, Lai Y, et al. In vitro methods to support transporter evaluation in drug discovery and development. Clin Pharmacol Ther. 2013;94(1):95-112.

32. Konig J, Zolk O, Singer K, Hoffmann C, Fromm MF. Doubletransfected MDCK cells expressing human OCT1/MATE1 or OCT2/MATE1: determinants of uptake and transcellular translocation of organic cations. Br J Pharmacol. 2011;163(3):546-55.

33. Ho ES, Lin DC, Mendel DB, Cihlar T. Cytotoxicity of antiviral nucleotides adefovir and cidofovir is induced by the expression of human renal organic anion transporter 1. J Am Soc Nephrol. 2000;11(3):383-93.

34. Müller F, König J, Hoier E, Mandery K, Fromm MF. Role of organic cation transporter OCT2 and multidrug and toxin extrusion proteins MATE1 and MATE2-K for transport and drug interactions of the antiviral lamivudine. Biochem Pharmacol. 2013;86(6):808-15.

35. Lash LH, Putt DA, Cai HL. Membrane transport function in primary cultures of human proximal tubular cells. Toxicology. 2006;228(2-3):200-18.

36. Brown CD, Sayer R, Windass AS, Haslam IS, De Broe ME, D'Haese PC, et al. Characterisation of human tubular cell monolayers as a model of proximal tubular xenobiotic handling. Toxicol Appl Pharmacol. 2008;233(3):428-38.

37. Nozaki Y, Kusuhara H, Kondo T, Hasegawa M, Shiroyanagi $\mathrm{Y}$, Nakazawa $\mathrm{H}$, et al. Characterization of the uptake of organic anion transporter (OAT) 1 and OAT3 substrates by human kidney slices. J Pharmacol Exp Ther. 2007;321(1):362-9.

38. Watanabe T, Kusuhara H, Debori Y, Maeda K, Kondo T, Nakayama $\mathrm{H}$, et al. Prediction of the overall renal tubular secretion and hepatic clearance of anionic drugs and a renal drug-drug interaction involving organic anion transporter 3 in humans by in vitro uptake experiments. Drug Metab Dispos. 2011;39(6):1031-8.

39. Nagle MA, Truong DM, Dnyanmote AV, Ahn S-Y, Eraly SA, $\mathrm{Wu} \mathrm{W}$, et al. Analysis of three-dimensional systems for developing and mature kidneys clarifies the role of OAT1 and OAT3 in antiviral handling. J Biol Chem. 2011;286(1):243-51.

40. Takai N, Tanaka Y, Saji H. Quantification of small molecule drugs in biological tissue sections by imaging mass spectrometry using surrogate tissue-based calibration standards. Mass Spectrom (Tokyo). 2014;3(1):A0025.

41. Bens M, Vandewalle A. Cell models for studying renal physiology. Pfluegers Arch/Eur J Physiol. 2008;457(1):1-15.

42. Glube N, Giessl A, Wolfrum U, Langguth P. Caki-1 cells represent an in vitro model system for studying the human proximal tubule epithelium. Nephron Exp Nephrol. 2007;107(2):e47-56.

43. Aschauer L, Carta G, Vogelsang N, Schlatter E, Jennings P. Expression of xenobiotic transporters in the human renal proximal tubule cell line RPTEC/TERT1. Toxicol In Vitro. 2015;30(1):95-105.

44. Knops N, van den Heuvel LP, Masereeuw R, Bongaers I, de Loor H, Levtchenko E, et al. The functional implications of common genetic variation in CYP3A5 and ABCB1 in human proximal tubule cells. Mol Pharm. 2015;12(3):758-68.

45. Mutsaers HAM, Wilmer MJG, Reijnders D, Jansen J, van den Broek PHH, Forkink M, et al. Uremic toxins inhibit renal metabolic capacity through interference with glucuronidation and mitochondrial respiration. Biochim Biophys Acta. 2013;1832(1):142-50.

46. Hilgendorf C, Ahlin G, Seithel A, Artursson P, Ungell AL, Karlsson J. Expression of thirty-six drug transporter genes in human intestine, liver, kidney, and organotypic cell lines. Drug Metab Dispos. 2007;35(8):1333-40.

47. Nieskens TTG, Peters JGP, Schreurs MJ, Smits N, Woestenenk R, Jansen K, et al. A human renal proximal tubule cell line with stable organic anion transporter 1 and 3 expression predictive for antiviral-induced toxicity. AAPS J. 2016;18(2):465-75.
48. Glavinas H, Mehn D, Jani M, Oosterhuis B, Heredi-Szabo K, Krajcsi P. Utilization of membrane vesicle preparations to study drug-ABC transporter interactions. Expert Opin Drug Met. 2008;4(6):721-32.

49. Karlsson JE, Heddle C, Rozkov A, Rotticci-Mulder J, Tuvesson $\mathrm{O}$, Hilgendorf $\mathrm{C}$, et al. High-activity P-glycoprotein, multidrug resistance protein 2, and breast cancer resistance protein membrane vesicles prepared from transiently transfected human embryonic kidney 293-EpsteinBarr virus nuclear antigen cells. Drug Metab Dispos. 2010;38(4):705-14.

50. Jang K-J, Mehr AP, Hamilton GA, McPartlin LA, Chung S, Suh K-Y, et al. Human kidney proximal tubule-on-a-chip for drug transport and nephrotoxicity assessment. Integr Biol (Camb). 2013;5(9):1119-29.

51. Wilmer MJ, Ng CP, Lanz HL, Vulto P, Suter-Dick L, Masereeuw R. Kidney-on-a-chip technology for drug-induced nephrotoxicity screening. Trends Biotechnol. 2015. doi:10.1016/ j.tibtech.2015.11.001.

52. Sciancalepore AG, Sallustio F, Girardo S, Passione LG, Camposeo A, Mele E, et al. A bioartificial renal tubule device embedding human renal stem/progenitor cells. PLoS One. 2014;9(1):e87496.

53. Zamek-Gliszczynski MJ, Lee CA, Poirier A, Bentz J, Chu X, Ellens $\mathrm{H}$, et al. ITC recommendations for transporter kinetic parameter estimation and translational modeling of transportmediated PK and DDIs in humans. Clin Pharmacol Ther. 2013;94(1):64-79.

54. Ménochet K, Kenworthy KE, Houston JB, Galetin A. Simultaneous assessment of uptake and metabolism in rat hepatocytes: a comprehensive mechanistic model. J Pharmacol Exp Ther. 2012;341(1):2-15.

55. Kalvass JC, Pollack GM. Kinetic considerations for the quantitative assessment of efflux activity and inhibition: implications for understanding and predicting the effects of efflux inhibition. Pharm Res. 2007;24(2):265-76.

56. Korzekwa K, Nagar S. Compartmental models for apical efflux by P-glycoprotein: part 2-a theoretical study on transporter kinetic parameters. Pharm Res. 2014;31(2):335-46.

57. Nagar S, Tucker J, Weiskircher EA, Bhoopathy S, Hidalgo IJ, Korzekwa K. Compartmental models for apical efflux by $\mathrm{P}$ glycoprotein - part 1: evaluation of model complexity. Pharm Res. 2014;31(2):347-59.

58. Ghosh A, Scott DO, Maurer TS. Towards a unified model of passive drug permeation I: origins of the unstirred water layer with applications to ionic permeation. Eur J Pharm Sci. 2014;52:109-24.

59. Burt HJ, Neuhoff S, Almond L, Gaohua L, Harwood MD, Jamei M, et al. Metformin and cimetidine: physiologically based pharmacokinetic modelling to investigate transporter mediated drug-drug interactions. Eur. J. Pharm. Sci. 2016 6/ $10 / ; 88: 70-82$.

60. Marieb EN, Hoehn K. Human anatomy \& physiology. 10th ed. New York: Pearson Education; 2015.

61. Weinstein AM. A mathematical model of rat proximal tubule and loop of Henle. Am J Physiol Renal Physiol. 2015;308(10):F1076-97.

62. Randall TS. Kidney modeling and systems physiology. Wiley Interdiscip Rev Syst Biol Med. 2009;1(2):172-90.

63. Darmady E, Offer J, Woodhouse M. The parameters of the ageing kidney. J Pathol. 1973;109(3):195-207.

64. Hoy WE, Douglas-Denton RN, Hughson MD, Cass A, Johnson $\mathrm{K}$, Bertram JF. A stereological study of glomerular number and volume: preliminary findings in a multiracial study of kidneys at autopsy. Kidney Int. 2003;63:S31-7.

65. Nyengaard J, Bendtsen T. Glomerular number and size in relation to age, kidney weight, and body surface in normal man. Anat Rec. 1992;232(2):194-201.

66. Bakker J, Olree M, Kaatee R, de Lange EE, Moons KG, Beutler JJ, et al. Renal volume measurements: accuracy and repeatability of US compared with that of MR imaging 1. Radiology. 1999;211(3):623-8.

67. Di Leo G, Di Terlizzi F, Flor N, Morganti A, Sardanelli F. Measurement of renal volume using respiratory-gated MRI in subjects without known kidney disease: intraobserver, 
interobserver, and interstudy reproducibility. Eur J Radiol. 2011;80(3):e212-6.

68. Wang X, Vrtiska TJ, Avula RT, Walters LR, Chakkera HA, Kremers WK, et al. Age, kidney function, and risk factors associate differently with cortical and medullary volumes of the kidney. Kidney Int. 2014;85(3):677-85.

69. DeWoskin RS, Thompson CM. Renal clearance parameters for PBPK model analysis of early lifestage differences in the disposition of environmental toxicants. Regul Toxicol Pharmacol. 2008;51(1):66-86.

70. Ozmen C, Akin D, Bilek S, Bayrak A, Senturk S, Nazaroglu H. Ultrasound as a diagnostic tool to differentiate acute from chronic renal failure. Clin Nephrol. 2010;74(1):46-52.

71. Kriz W, Bankir L, Bulger RE, Burg MB, Goncharevskaya OA, Imai $\mathrm{M}$, et al. A standard nomenclature for structures of the kidney. Pflugers Arch. 1988;411(1):113-20.

72. Nordsletten DA, Blackett S, Bentley MD, Ritman EL, Smith NP. Structural morphology of renal vasculature. Am J Physiol Heart Circ Physiol. 2006;291(1):H296-309.

73. Levey AS, Becker C, Inker LA. Glomerular filtration rate and albuminuria for detection and staging of acute and chronic kidney disease in adults: a systematic review. JAMA. 2015;313(8):837-46.

74. Delanaye P, Schaeffner E, Ebert N, Cavalier E, Mariat C, Krzesinski J-M, et al. Normal reference values for glomerular filtration rate: what do we really know? Nephrol Dial Transplant. 2012;27(7):2664-72.

75. Pai MP. Estimating the glomerular filtration rate in obese adult patients for drug dosing. Adv Chronic Kidney Dis. 2010;17(5):e53-62.

76. Malmgren L, McGuigan FE, Berglundh S, Westman K, Christensson A, Åkesson K. Declining estimated glomerular filtration rate and its association with mortality and comorbidity over 10 years in elderly women. Nephron. 2015;130(4):17-27.

77. Weitzman RE, Kleeman CR. The clinical physiology of water metabolism: part II: renal mechanisms for urinary concentration; diabetes insipidus. West J Med. 1979;131(6):486.

78. Bennett CM, Brenner BM, Berliner RW. Micropuncture study of nephron function in the rhesus monkey. J Clin Invest. 1968;47(1):203.

79. Goldstein LJ, Rypins EB. A computer model of the kidney. Comput Methods Programs Biomed. 1992;37(3):191-203.

80. Malnic G, Aires MDM, Giebisch G. Micropuncture study of renal tubular hydrogen ion transport in the rat. Am J Physiol. 1972;222(1):147-58.

81. Puelles VG, Hoy WE, Hughson MD, Diouf B, Douglas-Denton $\mathrm{RN}$, Bertram JF. Glomerular number and size variability and risk for kidney disease. Curr Opin Nephrol Hypertens. 2011;20(1):7-15.

82. Kriz W. Structural organization of the renal medulla: comparative and functional aspects. Am J Physiol. 1981;241(1):R3.

83. Nyengaard J, Flyvbjerg A, Rasch R. The impact of renal growth, regression and regrowth in experimental diabetes mellitus on number and size of proximal and distal tubular cells in the rat kidney. Diabetologia. 1993;36(11):1126-31.

84. Cummings BS, Lash LH. Metabolism and toxicity of trichloroethylene and S-(1,2-dichlorovinyl)-L-cysteine in freshly isolated human proximal tubular cells. Toxicol Sci. 2000;53(2):458-66.

85. Al-Jahdari WS, Yamamoto K, Hiraoka H, Nakamura K, Goto F, Horiuchi R. Prediction of total propofol clearance based on enzyme activities in microsomes from human kidney and liver. Eur J Clin Pharmacol. 2006;62(7):527-33.

86. Kitagawa H, Kamataki T. Studies on drug metabolism. XII. Activity of liver microsomal drug-metabolizing enzymes in human liver. Chem Pharm Bull. 1971;19(4):827-30.

87. Pacifici GM, Franchi M, Bencini C, Repetti F, Dilascio N, Muraro GB. Tissue distribution of drug-metabolizing-enzymes in humans. Xenobiotica. 1988;18(7):849-56.

88. Jakobsson SV, Cinti DL. Studies on cytochrome P-450containing mono-oxygenase system in human kidney-cortex microsomes. J Pharmacol Exp Ther. 1973;185(2):226-34.
89. Barter ZE, Chowdry JE, Harlow JR, Snawder JE, Lipscomb JC, Rostami-Hodjegan A. Covariation of human microsomal protein per gram of liver with age: absence of influence of operator and sample storage may justify interlaboratory data pooling. Drug Metab Dispos. 2008;36(12):2405-9.

90. Scotcher D, Billington S, Brown J, Jones C, Brown C, RostamiHodjegan A, et al. Are we underestimating drug metabolism in kidney? Higher values for microsomal protein content of human kidney. Poster W4311, presented at the AAPS Annual Meeting and Exposition; Orlando, FL, October 2015.

91. Court MH, Zhang XL, Ding XX, Yee KK, Hesse LM, Finel M. Quantitative distribution of mRNAs encoding the 19 human UDP-glucuronosyltransferase enzymes in 26 adult and 3 fetal tissues. Xenobiotica. 2012;42(3):266-77.

92. Sato Y, Nagata M, Tetsuka K, Tamura K, Miyashita A, Kawamura A, et al. Optimized methods for targeted peptidebased quantification of human uridine $5^{\prime}$-diphosphateglucuronosyltransferases in biological specimens using liquid chromatography-tandem mass spectrometry. Drug Metab Dispos. 2014;42(5):885-9.

93. Margaillan G, Rouleau M, Fallon JK, Caron P, Villeneuve L, Turcotte V, et al. Quantitative profiling of human renal UDPglucuronosyltransferases and glucuronidation sctivity: a comparison of normal and tumoral kidney tissues. Drug Metab Dispos. 2015;43(4):611-9.

94. Al Feteisi H, Achour B, Rostami-Hodjegan A, Barber J. Translational value of liquid chromatography coupled with tandem mass spectrometry-based quantitative proteomics for in vitro-in vivo extrapolation of drug metabolism and transport and considerations in selecting appropriate techniques. Expert Opin Drug Met. 2015;11(9):1357-69.

95. Harwood M, Achour B, Russell M, Carlson G, Warhurst G, Rostami-Hodjegan A. Application of an LC-MS/MS method for the simultaneous quantification of human intestinal transporter proteins absolute abundance using a QconCAT technique. J Pharm Biomed Anal. 2015;110:27-33.

96. Badée J, Achour B, Rostami-Hodjegan A, Galetin A. Meta-analysis of expression of hepatic organic aniontransporting polypeptide (OATP) transporters in cellular systems relative to human liver tissue. Drug Metab Dispos. 2015;43(4):424-32.

97. Uchida Y, Ohtsuki S, Katsukura Y, Ikeda C, Suzuki T, Kamiie J, et al. Quantitative targeted absolute proteomics of human blood-brain barrier transporters and receptors. J Neurochem. 2011;117(2):333-45.

98. Uchida Y, Toyohara T, Ohtsuki S, Moriyama Y, Abe T, Terasaki T. Quantitative targeted absolute proteomics for 28 transporters in brush-border and basolateral membrane fractions of rat kidney. J Pharm Sci. 2016;105(2):1011-6.

99. Brouwer K, Aleksunes L, Brandys B, Giacoia G, Knipp $\mathrm{G}$, Lukacova V, et al. Human ontogeny of drug transporters: review and recommendations of the Pediatric Transporter Working Group. Clin Pharmacol Ther. 2015;98(3):266-87.

100. Fletcher JS, Vickerman JC. Secondary ion mass spectrometry: characterizing complex samples in two and three dimensions. Anal Chem. 2012;85(2):610-39.

101. Hogg K, Thomas J, Ashford D, Cartwright J, Coldwell R, Weston DJ, et al. Quantification of proteins by flow cytometry: quantification of human hepatic transporter $\mathrm{P}-\mathrm{gp}$ and OATP1B1 using flow cytometry and mass spectrometry. Methods. 2015;82:38-46.

102. Chen N, Aleksa K, Woodland C, Rieder M, Koren G. Ontogeny of drug elimination by the human kidney. Pediatr Nephrol. 2006;21(2):160-8.

103. Komatsu T, Hiasa M, Miyaji T, Kanamoto T, Matsumoto T, Otsuka M, et al. Characterization of the human MATE2 protoncoupled polyspecific organic cation exporter. Int J Biochem Cell Biol. 2011;43(6):913-8. 